\title{
Amplification of $16 \mathrm{~S}$ rRNA sequences to detect Mycobacterium paratuberculosis
}

\author{
J. W. B. VAN DER GIESSEN, A. EgER*, J. HAAGSMA*, R. M. HARING, W. GAASTRA and \\ B. A. M. VAN DER ZEIJST†
}

Department of Bacteriology, Institute of Infectious Diseases and Immunology, School of Veterinary Medicine, University of Utrecht, PO Box 80.165, 3508 TD Utrecht and "Central Veterinary Institute, PO Box 65, 8200 AB Lelystad, The Netherlands

\begin{abstract}
Summary. A probe based on $16 \mathrm{~S}$ ribosomal RNA (rRNA) sequences was developed to detect Mycobacterium paratuberculosis, the causative agent of Johne's disease in cattle. Three universal primers were used to sequence the amplified fragments of the 16S rRNA gene of various species of mycobacteria. When the nucleotide sequences were analysed, a deletion was detected in the sequence of the fast-growing species. An oligonucleotide probe (P) directed to this region was synthesised and hybridised directly with total RNA of various mycobacterial strains in a dot-spot assay. The probe detected $M$. paratuberculosis, some other slow-growing mycobacteria of the $M$. avium-intracellulare (MAI) complex, and one atypical strain, $M$. gordonae. To increase the sensitivity of the probe, a 413-bp fragment of the $16 \mathrm{~S}$ rRNA gene of $M$. paratuberculosis between $\mathrm{P}$ and a second oligonucleotide primer was amplified and hybridised with a $M$. paratuberculosis/M. avium-specific probe. When faecal samples of cattle were tested, all culture-positive samples were positive in the PCR assay.
\end{abstract}

\section{Introduction}

Paratuberculosis or Johne's disease, a chronic progressive disease in ruminants, is caused by $\mathbf{M y c o -}$ bacterium paratuberculosis. ${ }^{1}$ Johne's disease causes substantial economic losses in the cattle industry ${ }^{1}$ and its control is hampered by the lack of a rapid and reliable test to detect bacteria shed by individual cattle. Immunologically-based tests to detect Johne's disease have long been used, but these tests are neither sensitive nor specific enough. $M$. paratuberculosis is a slow-growing mycobacterium, closely related to the M. avium-intracellulare (MAI) complex, which belong to Runyon group III..$^{2-4}$ Until recently, the only reliable method of detecting $M$. paratuberculosis was to culture the bacteria from faeces. ${ }^{5,6}$ Culture however, requires between 6 weeks and 6 months.

Runyon classified mycobacteria on the basis of their growth rate and pigmentation. ${ }^{7}$ Stahl et al ${ }^{8}$ sequenced $16 \mathrm{~S}$ ribosomal (r)RNA of many mycobacteria and used the data to classify $M$. paratuberculosis, $M$. avium and $M$. intracellulare, together with $M$. scrofulaceum, in one group. Analyses of the sequences of amplified 16S rRNA genes of several mycobacteria by Rogall et al. ${ }^{9}$ confirmed that $M$. avium and $M$. paratuberculosis are closely related; their $16 \mathrm{~S}$ rRNA sequences showed $99.9 \%$ identity. However, they could not confirm the close relatedness of these mycobacteria and $M$. scrofulaceum.
The application of DNA probes offers an alternative approach to detecting bacteria, and in this respect probes directed at rRNA sequences have been shown to be useful. ${ }^{10,11}$ DNA probes directed to the $16 \mathrm{~S}$ rRNA of bacteria of the MAI complex in culture are available commercially. ${ }^{12}$ We detected $M$. paratuberculosis with the Gen-probe kit for the MAI complex ${ }^{12}$ (unpublished results). This probe, however, still relies on lengthy culturing of the bacteria. Although DNA probes offer the possibility of detecting micro-organisms directly in clinical material, the sensitivity of these tests is still too low. The sensitivity can be increased enormously by first amplifying the DNA of specific pathogens in clinical material by the polymerase chain reaction (PCR) technique ${ }^{13}$ and then detecting the amplified DNA with a labelled DNA probe. ${ }^{14}$

In the present study, we used an oligonucleotide probe (P) complementary to the 16S rRNA of $M$. paratuberculosis isolated from cattle with Johne's disease. The probe was used directly to detect rRNA and to detect $M$. paratuberculosis in faeces of infected animals after amplifying the DNA of the 16S rRNA gene.

\section{Materials and methods}

\section{Bacterial strains, faecal samples and growth conditions}

All strains used in this study (table I) were grown on Middlebrook $7 \mathrm{H} 10$ medium at $37^{\circ} \mathrm{C}$. Strains that 
Table I. Source and origin of mycobacteria and control strains used in this study and their specificity to probe $\mathbf{P}$ in dot-spot hybridisation assay

\begin{tabular}{|c|c|c|c|}
\hline Bacterial strains & Source & Origin & $\begin{array}{c}\text { Specificity to } \\
\text { probe } \mathrm{P}\end{array}$ \\
\hline M. avium D4 & Chicken & Lelystad $\dagger$ & $+^{*}$ \\
\hline$M$. avium serotype 6 & Human & Lelystad & + \\
\hline$M$. avium serotype 19 & Pig & Lelystad & + \\
\hline M. paratuberculosis JII & Lab. strain & Weybridget & + \\
\hline M. paratuberculosis $\mathrm{J} 2 \mathrm{~A}$ & Lab. strain & Weybridge & $+^{*}$ \\
\hline M. paratuberculosis Teps & Lab. strain & Weybridge & + \\
\hline$M$ paratuberculosis $316 \mathrm{~F}$ & Lab. strain & Weybridge & + \\
\hline M. paratuberculosis $\mathrm{C}$ & Lab. strain & Weybridge & + \\
\hline M. paratuberculosis Linda & Human & Connecticut & + \\
\hline M. paratuberculosis 52991 & Human & Lelystad & + \\
\hline M. paratuberculosis B619 & Cow & Lelystad & + \\
\hline M. paratuberculosis $\mathrm{H} 100$ & Cow & Lelystad & + \\
\hline M. paratuberculosis B854 & Cow & Lelystad & + \\
\hline M. paratuberculosis H159 & Cow & Lelystad & + \\
\hline M. paratuberculosis $\mathrm{C} 303$ & Cow & Lelystad & + \\
\hline M. paratuberculosis Zw95 & Cow & Lelystad & + \\
\hline M.paratuberculosis C538 & Cow & Lelystad & + \\
\hline M. paratuberculosis $\mathrm{H} 92$ & Cow & Lelystad & + \\
\hline M. paratuberculosis $\mathrm{H} 109$ & Cow & Lelystad & + \\
\hline M. paratuberculosis $\mathrm{C} 456$ & Cow & Lelystad & + \\
\hline M. gastri & Pig & Lelystad & $-*$ \\
\hline$M$. marinum & Fish & Lelystad & $-{ }^{*}$ \\
\hline M. triviale & Anteater & Lelystad & $-*$ \\
\hline M. terrae & Buzzard & Lelystad & $-^{*}$ \\
\hline M. kansasii 1 & Cow & Lelystad & $-{ }^{*}$ \\
\hline M. gordonae & Fish & Lelystad & $+^{*}$ \\
\hline M. scrofulaceum & Cow & Lelystad & $-*$ \\
\hline M. kansasii 2 & Cow & Lelystad & - \\
\hline M.phlei 82 & Lab. strain & Weybridge & - \\
\hline M. fortuitum & Pig & Lelysted & - \\
\hline M. chelonei & Lion & Lelystad & - \\
\hline M. smegmatis & Lab. strain & Lelystad & - \\
\hline Escherichia coli & Lab. strain & Utrecht\| & - \\
\hline
\end{tabular}

* Hybridisation at $45^{\circ} \mathrm{C}$.

+ Central Veterinary Institute, Lelystad.

¥ Central Veterinary Laboratory Weybridge.

$\S$ University of Connecticut, Connecticut

University of Utrecht, Utrecht.

were dependent on mycobactin for growth were cultured on medium supplemented with mycobactin $2 \mu \mathrm{g} / \mathrm{ml}$. Faecal samples of 10 cattle infected clinically or subclinically with $M$. paratuberculosis were cultured. Faecal samples of 10 culture-negative cattle were tested also.

\section{Preparation of mycobacterial RNA and DNA}

Mycobacterial cells $(100 \mathrm{mg})$ were washed three times with phosphate-buffered saline. The pelleted cells were suspended in $500 \mu$ l of RNA extraction mixture according to the method of Chomszynski. ${ }^{15}$ To the suspension, $500 \mu$ of water-saturated phenol (pH 4.0), $100 \mu \mathrm{l}$ of chloroform, $50 \mu \mathrm{l}$ of $2 \mathrm{~m}$ sodium acetate ( $\mathrm{pH} 4 \cdot 4$ ), and $200 \mu \mathrm{l}$ of $0 \cdot 1-\mathrm{mm}$ zirconium beads were added. The cells were disrupted in a MiniBeadbeater (Biospec Products, Bartesvilles, OK, USA) at high speed for 3 min. ${ }^{16}$ The tubes were cooled on ice for $15 \mathrm{~min}$ and then centrifuged for $20 \mathrm{~min}$ at $4^{\circ} \mathrm{C}$ at $10000 \mathrm{~g}$. The aqueous phase was shaken with an equal volume of chloroform: isoamylalcohol $(24: 1)$ and centrifuged for $10 \mathrm{~min}$ at $4^{\circ} \mathrm{C}$. RNA was precipitated from the aqueous phase by treatment with an equal volume of ice-cold isopropanol for $1 \mathrm{~h}$ at $-80^{\circ} \mathrm{C}$. Precipitated RNA was pelleted by centrifugation for $20 \mathrm{~min}$ at $10000 \mathrm{~g}$. The resulting RNA pellet was dissolved in $300 \mu$ l of the RNA extraction mixture and precipitated again. The RNA pellet was resuspended in ethanol $75 \%$, sedimented, vacuum dried, and then dissolved in $40 \mu$ l of water. The purity of RNA was checked by agarose gel electrophoresis.

The procedure described for isolating RNA was modified and used to isolate DNA. Pelleted cells $(100 \mathrm{mg})$ were resuspended in $500 \mu \mathrm{l}$ of $10 \mathrm{~mm}$ Tris$\mathrm{HCl}, 1 \mathrm{mM}$ EDTA (TE). To the suspension, $500 \mu \mathrm{l}$ of TE-saturated phenol (pH 7.5) and $200 \mu$ l of zirconium beads were added, and the mycobacteria were disrupted as described above. The tubes were centrifuged for $15 \mathrm{~min}$ at $8000 \mathrm{~g}$. The aqueous phase was trans- 
ferred to a new tube and shaken for 25 min with an equal volume of chloroform:isoamylalcohol:phenol $(24: 1: 25)$. After centrifugation, the water phase was extracted four times with ether, and DNA was precipitated by adding $200 \mu$ l of $3 \mathrm{M}$ sodium acetate ( $\mathrm{pH} 5 \cdot 2)$ and $700 \mu \mathrm{l}$ of ice-cold isopropanol. The DNA was pelleted, washed with ethanol $75 \%$, and dried. It was then resuspended in $500 \mu \mathrm{l}$ of $\mathrm{TE}$, treated with RNAase A $(10 \mathrm{mg} / \mathrm{ml})$ and stored at $4^{\circ} \mathrm{C}$.

\section{Isolation of $D N A$ from faecal material}

A 1-g sample of faeces was suspended in $10 \mathrm{ml}$ of $0 \cdot 2 \mathrm{M} \mathrm{NaOH} .{ }^{17}$ Bacteria were isolated by centrifugation for $30 \mathrm{~min}$ at $2000 \mathrm{~g}$ from the supernate of this supension obtained by centrifugation for $5 \mathrm{~min}$ at $100 \mathrm{~g}$. The pellet was resuspended in $0.5 \mathrm{ml}$ of $0.2 \mathrm{M}$ $\mathrm{NaOH}$. An equal volume of TE-saturated phenol:chloroform: isoamylalcohol $(25: 24: 1)$ and $200 \mu \mathrm{l}$ of $0 \cdot 5-\mathrm{mm}$ zirconium beads or $0 \cdot 1-\mathrm{mm}$ glass beads were added. The mycobacteria were disrupted in a Mini-Beadbeater as described above. Samples were stored on ice until centrifugation at $16000 \mathrm{~g}$ for $10 \mathrm{~min}$. From the aqueous phase, $100 \mu \mathrm{l}$ was transferred to a $1 \cdot 5-\mathrm{ml}$ microcentrifuge tube containing $20 \mu \mathrm{l}$ of activated silica (Sigma) and $900 \mu \mathrm{l}$ of guanidinisothiocyanate wash buffer. ${ }^{18}$ Samples were shaken by hand and left at room temperature for $10 \mathrm{~min}$. They were then centrifuged for $15 \mathrm{~s}$ at $16000 \mathrm{~g}$. Supernates were discarded and pellets were washed twice with ethanol $70 \%$, once with acetone, dried for $10 \mathrm{~min}$ at $56^{\circ} \mathrm{C}$ and eluted with $100 \mu \mathrm{l}$ of $\mathrm{H}_{2} \mathrm{O}$ for $10 \mathrm{~min}$ at $56^{\circ} \mathrm{C}$. This extract was stored at $-80^{\circ} \mathrm{C}$ until used in the PCR ( $1 \mu$ l per reaction).

\section{Amplification of $D N A$}

The PCR was performed as described by Saiki ${ }^{13}$ with some modifications. Briefly, $1 \mu \mathrm{g}$ of bacterial DNA was incubated in a total volume of $100 \mu \mathrm{l}$ containing $200 \mathrm{~mm} \mathrm{KCl}, 10 \mathrm{~mm}$ Tris- $\mathrm{HCl}(\mathrm{pH} \mathrm{8} 3$ ), $1.5 \mathrm{mM} \mathrm{MgCl}_{2}$, gelatin $0 \cdot 1 \mathrm{~g} / \mathrm{L}, 200 \mu \mathrm{M}$ each of dATP, dCTP, dGTP, dTTP (Boehringer, Mannheim) and $1 \mu \mathrm{M}$ of both primers. After heating for $8 \mathrm{~min}$ at $95^{\circ} \mathrm{C}$, 2.5 units of Taq DNA polymerase (Perkin Elmer/ Cetus) were added. Paraffin oil $(100 \mu \mathrm{l})$ was added to cover the reaction mixture. After 35 cycles $(1 \mathrm{~min}$ at $95^{\circ} \mathrm{C}, 2 \mathrm{~min}$ at $58^{\circ} \mathrm{C}$ and $3 \mathrm{~min}$ at $72^{\circ} \mathrm{C}$ ), $10 \mu \mathrm{l}$ of the amplified DNA was analysed by agarose gel electrophoresis.

\section{Sequencing of amplified DNA fragments}

The 16S rRNA gene was amplified by use of two universal primers, located at the $5^{\prime}$ and $3^{\prime}$ end of the gene, as descibed by Edwards et al. ${ }^{19}$ Amplified DNA fragments were directly sequenced according to the instructions of the manufacturer (Taq Track, Q5570, Promega) with labelled primers. The primers (A, B, C) hybridised to conserved regions in the $16 \mathrm{SrRNA} .{ }^{20}$

\section{Synthesis and labelling of oligonucleotide probes}

Oligonucleotides were synthesised with a 8600 Biosearch DNA synthesiser. The oligonucleotide probes were labelled at the $5^{\prime}$ ends with $\gamma-\left[{ }^{32} \mathrm{P}\right]-\mathrm{ATP}$ and $\mathrm{T}_{4}$ polynucleotide kinase (Boehringer, Mannheim) according to the method of Maniatis et al. ${ }^{21}$

\section{Dot-spot hybridisations of $r R N A$ and amplified $D N A$}

RNA was resuspended in $65 \mu \mathrm{l}$ of $20 \times \mathrm{SSC}(3 \mathrm{M}$ $\mathrm{NaCl}, 0.3 \mathrm{M}$ trisodium citrate), and $25 \mu \mathrm{l}$ of denaturating buffer containing TBE $(44.5 \mathrm{~mm}$ Tris, $1.5 \mathrm{~mm}$ sodium EDTA, $44.5 \mathrm{~mm}$ boric acid), formaldehyde $37 \%$ and formamide $50 \%$. The mixture was heated for $5 \mathrm{~min}$ at $65^{\circ} \mathrm{C}$, and $50 u \mathrm{l}$ was spotted on Hybond-N (Amersham International) with a minifold blotter. The blots were baked for $30 \mathrm{~min}$ at $80^{\circ} \mathrm{C}$ and hybridised with $\left[{ }^{32} \mathrm{P}\right]$-labelled probes for $18 \mathrm{~h}$.

The amplified DNA fragments $(4 \mu \mathrm{l})$ were spotted directly on Zetaprobe (BioRad). The blots were treated with $0.5 \mathrm{M} \mathrm{NaOH}-1.5 \mathrm{M} \mathrm{NaCl}$ for $10 \mathrm{~min}$ and neutralised with $1.0 \mathrm{M}$ Tris- $\mathrm{HCl}(\mathrm{pH} 8.0)-1.5 \mathrm{M} \mathrm{NaCl}$. They were then hybridised with $\gamma-\left[{ }^{32} \mathrm{P}\right]$-labelled probes for $2 \mathrm{~h}$ and washed in $5 \times \operatorname{SSPE}(0.75 \mathrm{M} \mathrm{NaCl}, 50 \mathrm{~mm}$ $\mathrm{NaH}_{2} \mathrm{PO}_{4}, 5 \mathrm{~mm}$ EDTA) containing sodium dodecyl sulphate $0.5 \mathrm{~g} / \mathrm{L}$. Fuji RX films were exposed to the blots for various times at $-70^{\circ} \mathrm{C}$.

\section{Results}

\section{Sequencing of PCR fragments}

Three oligonucleotides, A, B and $\mathrm{C},{ }^{20}$ that hybridised to $16 \mathrm{~S}$ rRNA of mycobacteria at locations corresponding to the 16S rRNA sequence of Escherichia coli ${ }^{22}-519-536$ (A), 907-920 (B), and 1392 1406 (C)-were used as primers (fig. 1). The 16S rRNA genes of $M$. paratuberculosis laboratory strain $\mathrm{J} 2 \mathrm{~A}$, two field strains B854 and C456, and strain Linda, isolated from a human patient with Crohn's disease, were partially sequenced. The $16 \mathrm{~S}$ rRNA genes of several other atypical mycobacteria were also sequenced (listed in table II). When the sequences from the various mycobacterial strains obtained with primers $\mathrm{B}$ and $\mathrm{C}$ were aligned, no major differences were found. Alignment of sequences obtained with primer A revealed a deletion in the $16 \mathrm{~S}$ rRNA of the fast-growing $M$. phlei and $M$. fortuitum strains and in the slow-growing $M$. scrofulaceum (table II). The sequence in this region showed some variation among the slow-growing mycobacteria, and was highly divergent from that of $E$. coli. The sequence of $M$. paratuberculosis in this region was used to derive a complementary oligonucleotide prohe (5'CCGAGAAAACCCGGAC3'), which was designated probe $P$, as shown in table II. 


\begin{tabular}{lrrrrr} 
primer $\mathrm{S}$ & primer $\mathrm{G}$ & primer $\mathrm{P}$ & primer $\mathrm{A}$ & primer $\mathrm{B}$ & primer $\mathrm{C}$ \\
\hline & & & & \\
\hline
\end{tabular}

$16 \mathrm{~S}$ rRNA

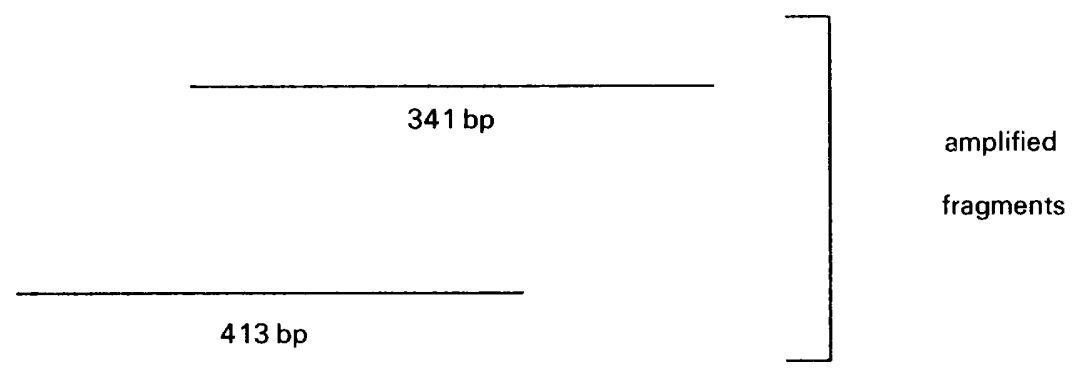

Fig. 1. Schematic representation of the $16 \mathrm{~S}$ rRNA of mycobacteria. The universal primers (A, B and C) were used for direct sequencing. The primer set $\mathrm{G}$ and $\mathrm{A}$ gave an amplified fragment of $341 \mathrm{bp}$ and the primer set $\mathrm{S}$ and $\mathbf{P}$ gave a fragment of $413 \mathrm{bp}$. The sizes of the amplified DNA fragments are indicated as determined by direct sequencing of the amplified $M$. paratuberculosis $16 \mathrm{~S}$ rRNA gene.

Table II. Sequence alignment of mycobacterial 16S rRNA located at the probe site as determined by sequencing the amplified fragments; numbering corresponds to the $E$. coli $16 \mathrm{~S}$ rR NA sequence ${ }^{22}$

\begin{tabular}{|c|c|}
\hline Mycobacteria & Sequence \\
\hline & 485 \\
\hline M. paratuberculosis J2A & CCUCUUUCACCAUCGACGAAGGUCCGGGUUUUCUCGGAUUG - ACGG \\
\hline M. paratuberculosis $\mathrm{B} 854$ & CCUCUUUCACCAUCGACGAAGGUCCGGGUUUUCUCGGAUUG-ACGG \\
\hline M. paratuberculosis $\mathrm{C} 456$ & CCUCUUUCACCAUCGACGAAGGUCCGGGUUUUCUCGGAUUG - ACGG \\
\hline M. paratuberculosis Linda & CCUNUUUCACCAUCGACGAAGGUCCGGGUUUUCUCGGAUUG - ACGG \\
\hline M. avium $\mathrm{D} 4$ & CCUCUUUCACCAUCGACGAAGGUCCGGGUUUUCUCGGAUUG - ACGG \\
\hline M. avium serotype 6 & CCUCUUUCACCAUCGACGAAGGUCCGGGUUUUCUCGGANNG - ACGG \\
\hline M. gordonae & CCUCUUUCACCAUCGACGAAGGUCCGGGUUUUCUCGGGCUG - ACGG \\
\hline M. gastri & CCUCUUUCACCAUCGACGAAGGUCCGGGUUGUCUCGGAUUG - ACGG \\
\hline M. scrofulaceum & CCUNUUUCGCCAGGGACGAAG $-\ldots-n-1-1-$ CGCAAGUGGACGG \\
\hline M. phlei & CCNCUUUCAGUAGGGACGAAG $\ldots \ldots \ldots$ CGUGAGUG - ACGG \\
\hline \multirow[t]{2}{*}{ M. fortuitum } & CCUCUUUCAAUAGGGACGAAG $-\cdots-\cdots$ \\
\hline & $3^{\prime}$ CAGGCCCAAAAGAGCC $5^{\prime}$ \\
\hline
\end{tabular}

$\mathrm{N}$, undetermined nucleotide.

\section{Dot-spot hybridisation of $r R N A$}

Probe $\mathrm{P}$ was tested in dot-spot hybridisation assays for its specificity for rRNA of several mycobacteria and E. coli. One of the universal sequence primers (A), which hybridises to all rRNA tested, was used as a control. Probe $\mathrm{P}$ reacted with all 10 field strains of $M$. paratuberculosis (fig. 2A), all $M$. paratuberculosis laboratory strains tested, and two human isolates, strain Linda and strain 52991 (fig. 2B); rRNA of $M$. avium strains also reacted in dot-spot hybridisation assays (fig. 2B), but rRNA of $M$. scrofulaceum did not (fig. 2C).

The probe clearly differentiated the fast-growing mycobacteria-M. chelonei, $M$. fortuitum, M. phleifrom the slow-growing $M$. paratuberculosis (fig. 2B). The specificity of the oligonucleotide probe was further tested in dot-spot assays with rRNA of several slowgrowing mycobacteria not belonging to the MAI complex. The rRNA of $M$. kansasii, $M$. gastri, $M$. marinum and $M$. gordonae hybridised weakly with the probe at $40^{\circ} \mathrm{C}$. When the hybridisation temperature was raised to $45^{\circ} \mathrm{C}, M$. paratuberculosis, bacteria of the MAI complex and the atypical mycobacterium, $M$. gordonae, were the only species that reacted positively (fig. $2 \mathrm{C}$ and data not shown). The specificity of probe $\mathrm{P}$ for all bacteria tested is summarised in table I.

With probe $\mathrm{P}$ in dot-spot assays it was possible to detect $5 \mathrm{ng}$ of RNA, corresponding to about $10^{7}$ bacteria.

\section{Amplification of chromosomal DNA}

The PCR was used to increase both the sensitivity and the specificity of the assay. One of the sequence primers (A) was used together with primer $G\left(5^{\prime}-\right.$ CTCAAGACGCATGTCTTCTGGTGGAAAGCTTTTGCGGT3'), which corresponds to nu- 


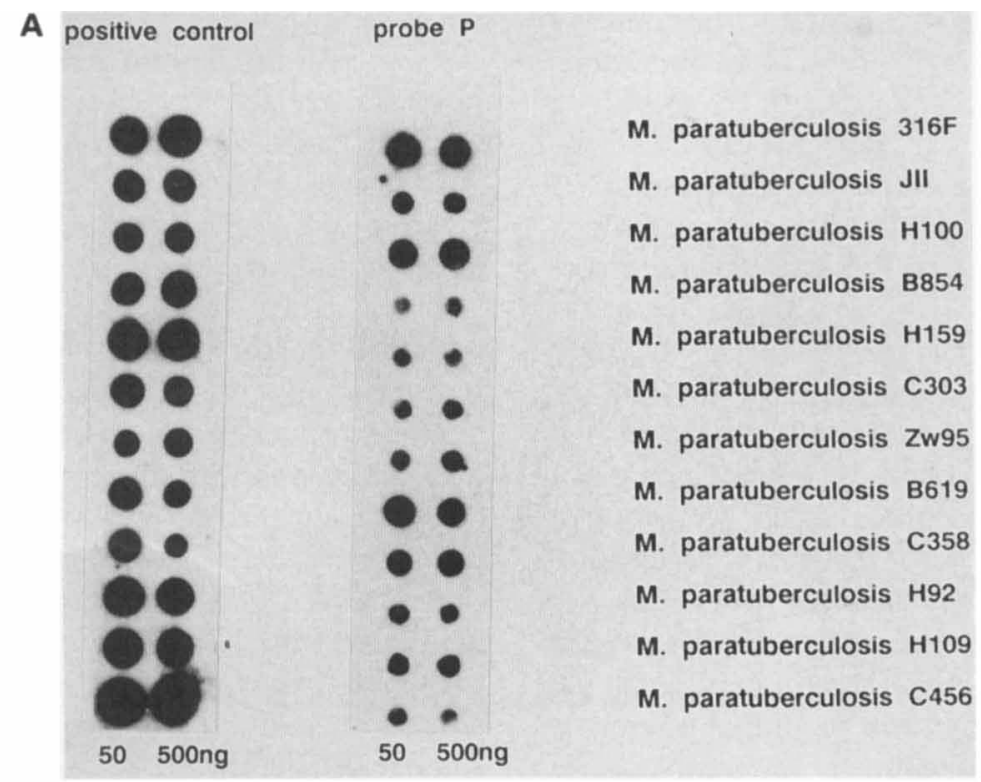

B
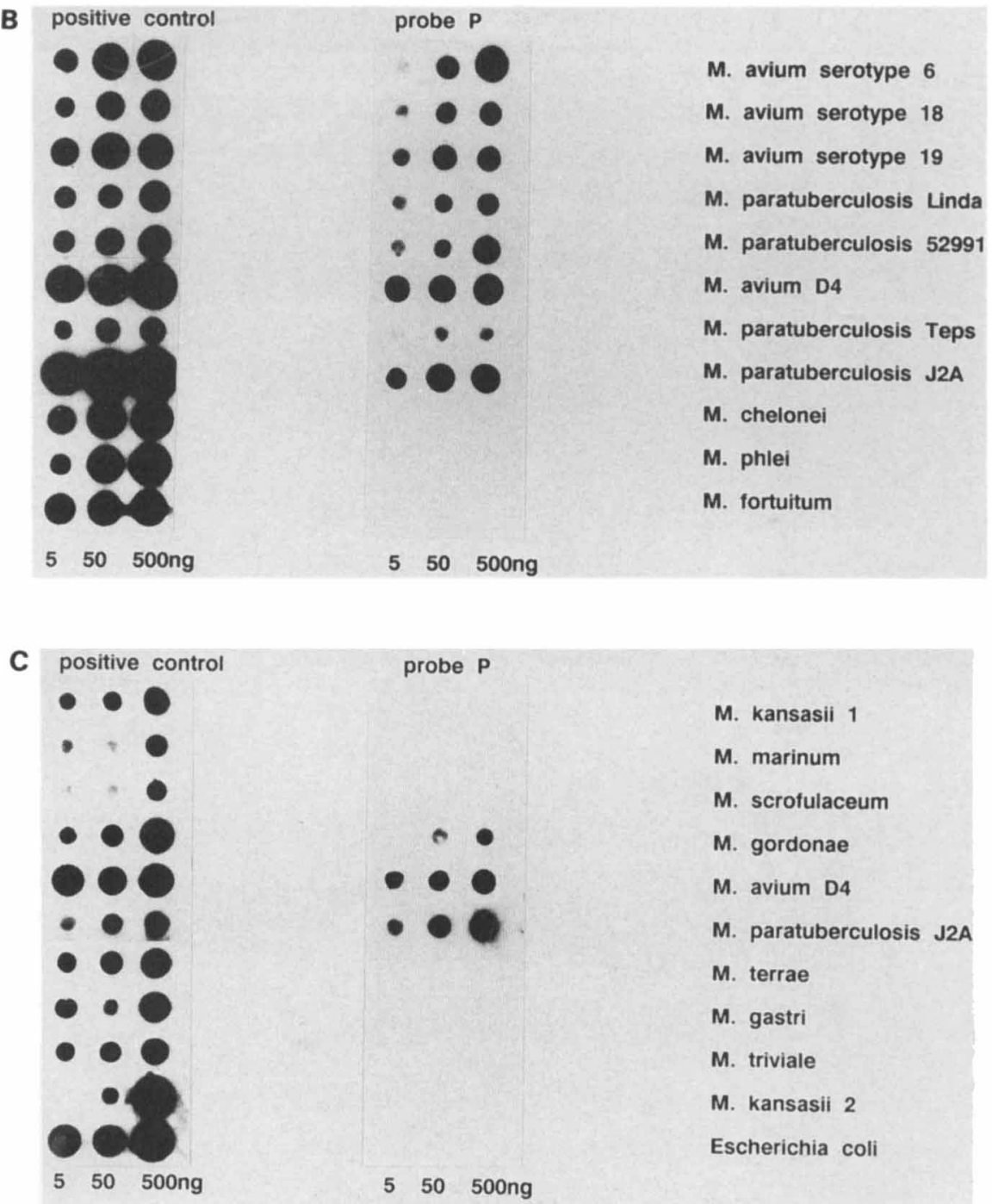

Fig. 2. Dot-spot hybridisation assays (A) Probe $P$ and a positive control probe (A) were hybridised to serial dilutions of RNA from $M$. paratuberculosis laboratory strains $316 \mathrm{~F}$ and JII and field strains of $M$. paratuberculosis isolated from cattle with paratuberculosis. (B) The same experiment with $M$. avium serotype 6, 18 and $19 ;$ two $M$. paratuberculosis strains Linda and $52991 ; M$. avium D4; $M$. paratuberculosis Teps and J2A; fast-growing mycobacteria $M$. chelonei, $M$. phlei, $M$. fortuitum. (C) Assay with atypical slow-growing mycobacteria, $M$. paratuberculosis $\mathrm{J} 2 \mathrm{~A}$ and $M$. avium D4 at an increased hybridisation temperature of $52^{\circ} \mathrm{C}$. 
cleotides $185-223$ of the $E$. coli 16 S rRNA sequence ${ }^{22}$ and which is used as a DNA probe in a commercial kit to detect $M$. avium in culture, ${ }^{23}$ to amplify a fragment of $341 \mathrm{bp}$. In fig. 1, the location of the primers and the size of the amplified fragments are shown schematically. Primers $G$ and A were combined in the PCR on chromosomal DNA of several mycobacteria. Apart from $M$. paratuberculosis, the other slow-growing mycobacteria ( $\boldsymbol{M}$. avium, $M$. kansasii, $M$. gordonae and $M$. gastri) and the fast-growing $M$. phlei yielded a product of the appropriate size (fig. 3A). These amplified fragments were spotted on nylon filters and hybridised to probe $\mathrm{P}$ at $52^{\circ} \mathrm{C}$. This resulted in the same specificity as with the direct hybridisation assay (fig. 3A). However, when this primer set was tested in the PCR on faeces of culture-negative cattle, an amplified fragment was also seen in the agarose gel (fig. 4A). After hybridising these amplified fragments to probe $P$, these culture-negative faecal samples gave negative results (fig. 4A). It seems likely that the primers hybridised non-specifically to DNA of saprophytic mycobacteria present in faeces. Apparently, this non-specific hybridisation interfered with specific hybridisation to $M$. paratuberculosis DNA. Only weak positive or negative reactions were observed after hybridisation to probe $P$ (fig. $4 B$ ).

To solve this problem, primer $P$, which did not react with saprophytic mycobacteria in the direct dot-spot hybridisations, was used in the PCR together with another primer, S (5'GTCGAACGGAAAGGCCT3'), which was derived from the $16 \mathrm{~S}$ rRNA sequence (8) at position 63-79 (fig. 1). When we tested this primer set on chromosomal DNA of several mycobacteria, DNA of fast-growing mycobacteria was not amplified (fig. 3B). After hybridisation of these amplified fragments to probe $\mathrm{G}$ at $72^{\circ} \mathrm{C}, M$. gordonae also gave negative results (fig. 3B). When these primers were tested in the PCR on faeces of two culture-

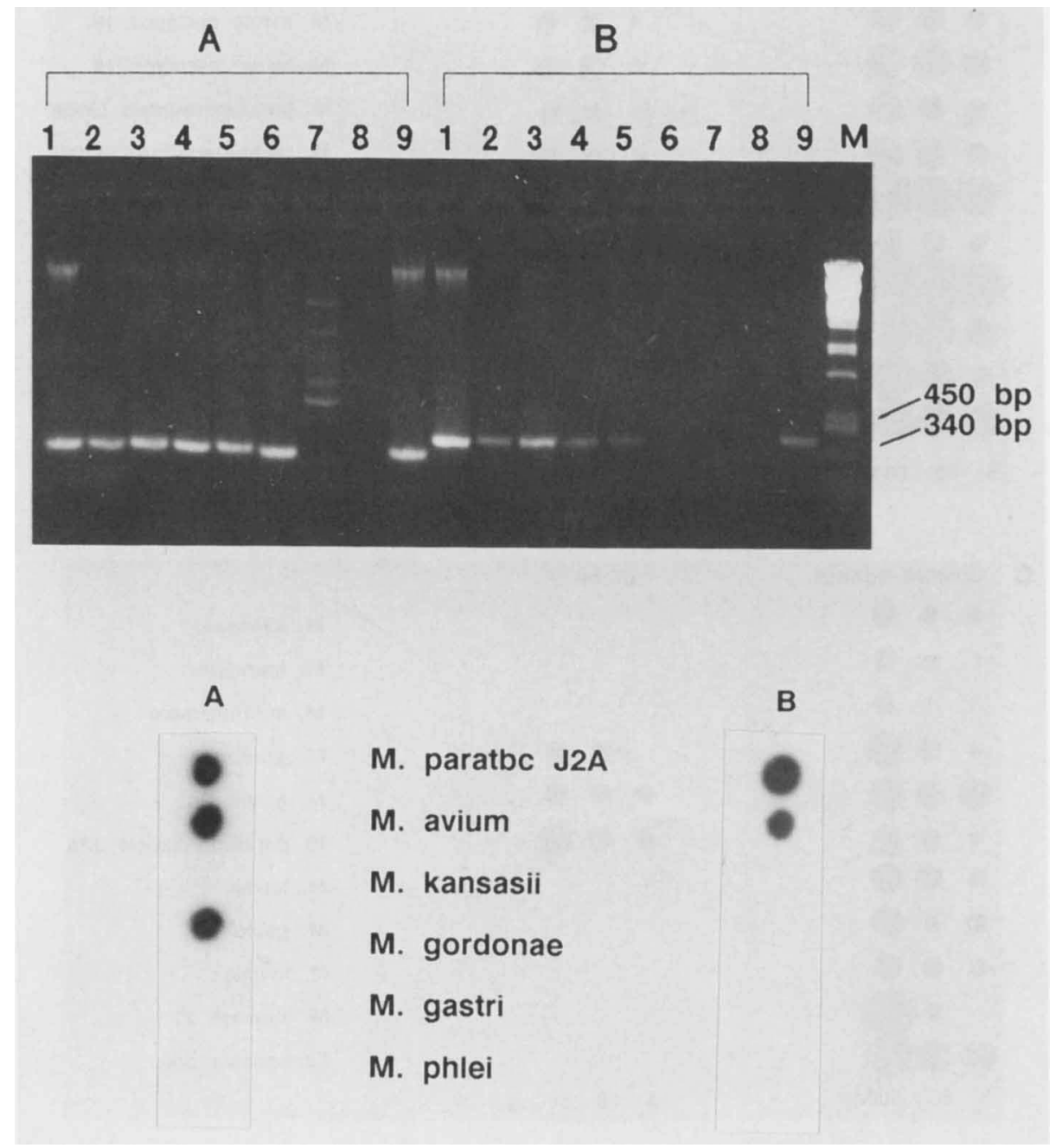

Fig. 3. Agarose gel electrophoresis of amplified DNAs of different mycobacteria. Amplification was done between (A) primers $\mathrm{G}$ and $\mathrm{A}$ (lanes 1-9), and (B) primers S and P (lanes 1-9). Lane $1, M$. paratuberculosis $J 2 A ; 2, M$. avium D4; 3, M. kansasii; 4, M. gordonae $1 ; 5, M$. gastri; 6, M. phlei; 7, E. coli; 8. negative control (PCR mixture without additions); 9, positive control (1 $\mu \mathrm{g}$ of $M$. paratuberculosis genomic DNA); M, phage $\lambda$ Pstl marker. Dot-spot hybridisation assay of amplified DNAs of $\boldsymbol{M}$. paratuberculosis $\mathrm{J} 2 \mathrm{~A}, \boldsymbol{M}$. avium D4, $M$. kansasii, $\boldsymbol{M}$. gordonae, $M$. gastri and $M$. phlei; amplification was between $(\mathrm{A})$ primers $\mathrm{G}$ and $\mathrm{A}$ hybridised with probe $\mathrm{P}$ at $52^{\circ} \mathrm{C}$, and $(\mathrm{B})$ primers $\mathrm{S}$ and $\mathrm{P}$ hybridised with probe $\mathrm{G}$ at $72^{\circ} \mathrm{C}$. 


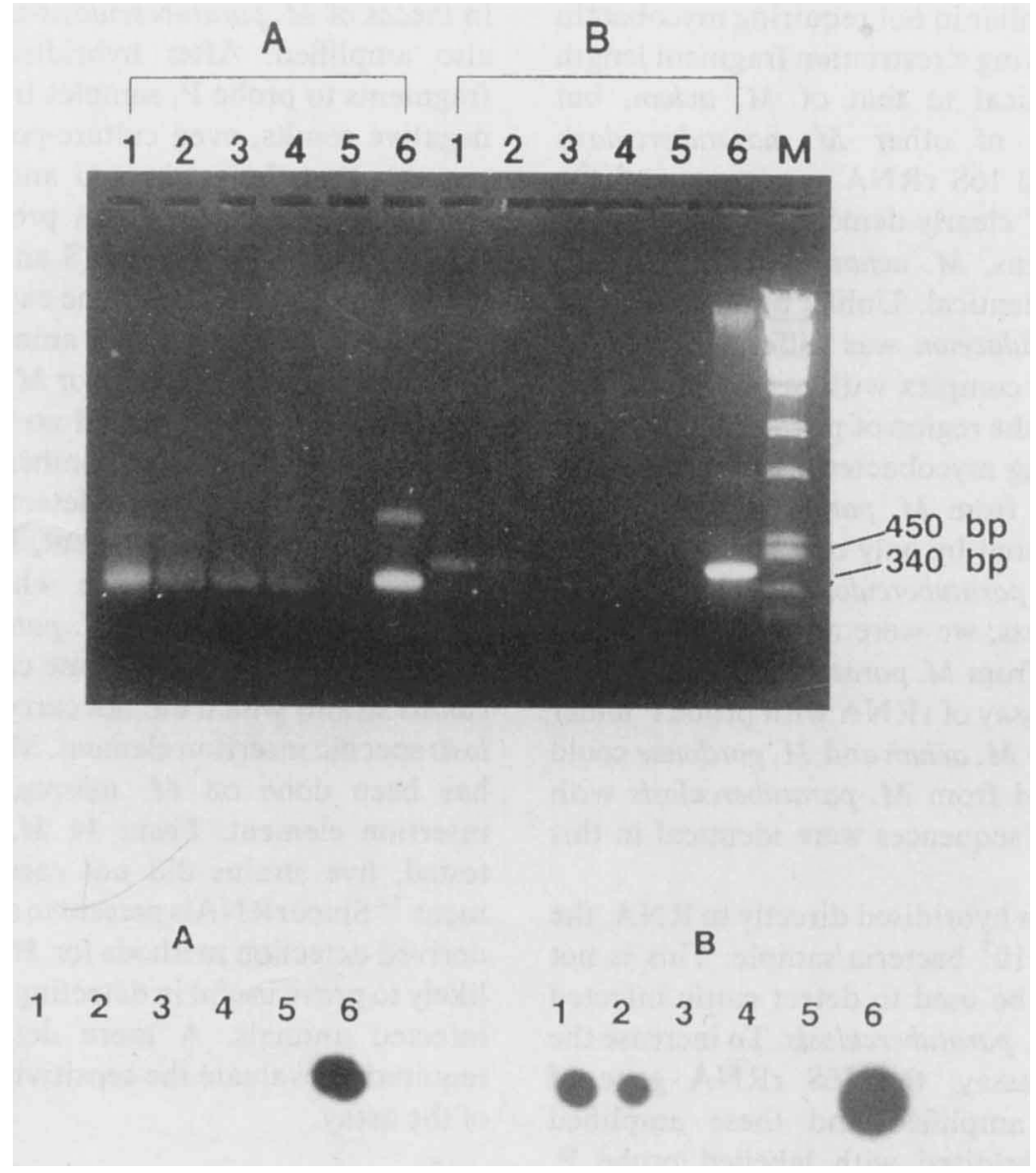

Fig. 4. Agarose gel electrophoresis of the amplified fragments of two culture-positive faecal samples (lanes 1 and 2 ) and the two culturenegative faecal samples ( 3 and 4). Amplification was between (A) primers $G$ and $A$ and (B) primers $S$ and $P$; lanes 5 and 6 , negative and positive controls; M $\lambda$ Pst1 marker. Dot-spot hybridisation of the culture-positive (1 and 2) and culture-negative (3 and 4) faecal samples (A) after amplification with primers $G$ and $A$ and hybridisation with probe $P$ at $52^{\circ} \mathrm{C}$ and (B) after amplification with primers $\mathrm{S}$ and $\mathrm{P}$ and hybridisation with probe $\mathrm{G}$ at $72^{\circ} \mathrm{C}(5$, negative controls; 6 , positive controls).

negative cattle, no amplification was seen (fig. 4B), whereas faecal samples of two culture-positive animals yielded the expected amplified fragment of $413 \mathrm{bp}$

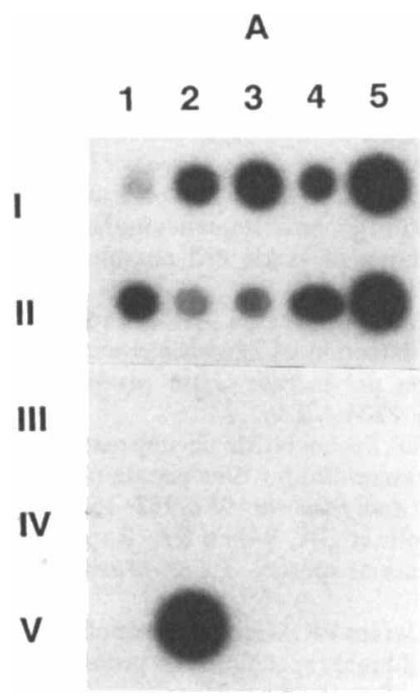

Fig. 5. Dot-spot hybridisation of 10 culture-positive faecal samples (I1-5 and II1-5), and 10 culture-negative faecal samples (III1-5 and IV1-5) after amplification with primer $S$ and $P$ and hybridisation to probe $\mathrm{G}$ at $72^{\circ} \mathrm{C} ; \mathrm{V} 1$ negative control; $\mathrm{V} 2$, positive control. hybridising to probe G (fig. 4B). Another 10 culturepositive and 10 culture-negative faecal samples of cattle were tested in the PCR with primers $S$ and $P$. All culture-positive cattle gave a positive hybridisation signal with probe G (fig. 5I and II), whereas the culture-negative cattle did not give such a signal (fig. 5III and IV).

\section{Discussion}

The 16S rRNA genes of various mycobacteria were amplified and partially sequenced. When the sequences were aligned, a highly diverged region was found. The $M$. paratuberculosis sequence of this region was used to synthesise a complementary oligonucleotide probe, designated P. All 16S rRNA sequences of $M$. paratuberculosis, laboratory strains and field strains, isolated from cattle, were identical. Stahl et al. ${ }^{8}$ also reported that the $16 \mathrm{~S}$ rRNA sequences of $M$. paratuberculosis and $M$. avium were similar. However, their conclusions were based on $M$. paratuberculosis strain 
18. This strain is peculiar in not requiring mycobactin for growth and in having a restriction fragment length polymorphism identical to that of $M$. avium, but different from that of other $M$. paratuberculosis strains. ${ }^{24}$ Our partial 16S rRNA sequences and the data of Rogall et al. ${ }^{9}$ clearly demonstrate that all $\boldsymbol{M}$. paratuberculosis strains, $M$. avium, and the Crohn's disease isolate are identical. Unlike Stahl et al., ${ }^{8}$ we found that $M$. scrofulaceum was different from the bacteria of the MAI complex with respect to the 16S rRNA sequences in the region of primer $A$.

Some slow-growing mycobacteria were more diffcult to discriminate from $M$. paratuberculosis, since their sequences differed by only one nucleotide from the sequence of $M$. paratuberculosis in the region of probe $P$. Nevertheless, we were able to differentiate these mycobacteria from $M$. paratuberculosis in a dotspot hybridisation assay of $r$ RNA with probe $P$ under stringent conditions. $M$. avium and $M$. gordonae could not be discriminated from $M$. paratuberculosis with probe $P$, since their sequences were identical in this region.

When probe $\mathbf{P}$ was hybridised directly to RNA, the detection limit was $10^{7}$ bacteria/sample. This is not sensitive enough to be used to detect cattle infected subclinically with $M$. paratuberculosis. To increase the sensitivity of the assay, the 16S rRNA gene of mycobacteria was amplified and these amplified fragments were hybridised with labelled probe $P$. When this assay was applied to faecal material, DNA in faeces of $\boldsymbol{M}$. paratuberculosis-negative animals was also amplified. After hybridising these amplified fragments to probe $P$, samples from all animals gave negative results, even culture-positive animals. This suggests that the primers $G$ and $A$ hybridised nonspecifically with other DNA present in the samples. Selection of other primers ( $S$ and $P$ ) in the PCR on faecal material resulted in the exclusive and complete detection of culture-positive animals. Although probe $\mathrm{G}$ is not absolutely specific for $M$. paratuberculosis, we and Hurley et al. ${ }^{25}$ detected no false-positive results from animals in a limited number of samples.

A more specific probe to detect $M$. paratuberculosis, based on an insertion element, has been reported. ${ }^{27}$ However, it is not known whether this insertion element is present in all $M$. paratuberculosis strains. Collins et al. ${ }^{26}$ described some caprine $M$. paratuberculosis strains which did not carry the $M$. paratuberculosis specific insertion element. More extensive testing has been done on $M$. tuberculosis with a similar insertion element. From $34 \mathrm{M}$. tuberculosis strains tested, five strains did not carry the insertion element. ${ }^{14}$ Since rRNAis present in all organisms, rRNAderived detection methods for $\boldsymbol{M}$. paratuberculosis are likely to prove useful in detecting. M. paratuberculosisinfected animals. A more detailed field study is required to evaluate the sensitivity and the specificity of the assay.

We thank $\mathbf{J}$. Vermeulen and $\mathbf{J}$. Pouw for technical assistance.

\section{References}

1. Chiodini RJ, Van Kruiningen HJ, Merkal RS. Ruminant paratuberculosis (Johne's disease): the current status and future prospects. Cornell Vet 1984; 74: 218-262.

2. Hurley SS, Splitter GA, Welch RA. Deoxyribonucleic acid relatedness of Mycobacterium paratuberculosis to other members of the family Mycobacteriaceae. Int $J$ Syst Bacteriol $1988 ; 38$ : 143-146.

3. Saxegaard F, Baess I. Relationship between Mycobacterium avium, Mycobacterium paratuberculosis and "wood pigeon mycobacteria." APMIS 1988; 96: $37-42$

4. Yoshimura HH, Graham DY. Nucleic acid hybridization studies of mycobactin-dependent mycobacteria. J Clin Microbiol 1988; 26: 1309-1312.

5. Merkal RS, Larsen AB, Kopecky KE, Ness RD. Comparison of examination and test methods for early detection of paratuberculous cattle. Am J Vet Res 1968; 29: 15331538 .

6. Merkal RS. Diagnostic methods for detection of paratuberculosis (Johne's disease). Proceedings of the 74th Annual Meeting of the US Animal Health Association 1970; 7 : 620-623.

7. Runyon EH, Wayne LG, Kubica GP. Mycobacteriaceae. In: Buchanan RE, Gibbons NE (eds) Bergey's Manual of determinative bacteriology, 8th edn. Baltimore, Williams and Wilkins Co. 1974: 681-701.

8. Stahl DA, Urbance JW. The division between fast- and slowgrowing species corresponds to natural relationships among the mycobacteria. $J$ Bacteriol $1990 ; 172 ; 116-124$.

9. Rogall T, Wolters J, Flohr T, Böttger EC. Towards a phylogeny and definition of species at the molecular level within the genus Mycobacterium. Int J Syst Bacteriol 1990; 40: 323330 .

10. Kohne DE. Application of DNA probe tests to the diagnosis of infectious disease. Am Clin Prod Review 1986; 5: 20-29.

11. Kohne D, Hogan J, Jonas V, Dean E, Adams TH. Novel approach for rapid and sensitive detection of microorganisms: DNA probes to rRNA. Microbiology 1986; 110 112.

12. Drake TA, Hindler JA, Berlin OGW, Bruckner DA. Rapid identification of Mycobacterium avium complex in culture using DNA probes J Clin Microbiol 1987; 25 : 1442-1445

13. Saiki RK, Scharf S, Faloona $F$ et al. Enzymatic amplification of $\beta$-globulin genomic sequence and restriction site analysis for diagnosis of sickle cell anemia. Science 1985; 230: 1350-1354.

14. Hermans PWM, Schuitema ARJ, Van Soolingen D et al. Specific detection of Mycobacterium tuberculosis complex strains by polymerase chain reaction. J Clin Microbiol 1990; 28 : 1204-1213.

15. Chomczynski P, Sacchi N. Single-step method of RNA isolation by acid guanidinium thiocyanate-phenol-chloroform extraction. Anal Biochem 1987; 162: 156-159.

16. Hurley SS, Splitter GA, Welch RA. Rapid lysis technique for mycobacterial species. J Clin Microbiol 1987; 25: 22272229.

17. Vary PH, Andersen PR, Green E, Hermon-Taylor J, McFadden JJ. Use of highly specific DNA probes and the polymerase chain reaction to detect $M$ ycobacterium paratuberculosis in Johne's disease. J Clin Microbiol 1990; 28: 933-937.

18. Boom R, Sol CJA, Salimans MMM, Jansen CL. Wertheim-van Dillen PME et al. Rapid and simple method for purification of nucleic acids. J Clin Microbiol 1990; 28: 495-503. 
19. Edwards U, Rogall T, Blöcker H, Emde M, Böttger EC. Isolation and direct complete nucleotide determination of entire genes. Characterization of a gene coding for $16 \mathrm{~S}$ ribosomal RNA. Nucleic Acids Res 1989; 19 : 7843-7853.

20. Lane DJ, Pace B, Olsen GJ, Stahl DA, Sogin ML, Pace NR. Rapid determination of $16 \mathrm{~S}$ ribosomal RNA sequences for phylogenetic analyses. Proc Natl Acad Sci USA 1985; 82 : 6955-6959.

21. Maniatis T. Molecular cloning: a laboratory manual. Cold Spring Harbor, NY, Cold Spring Harbor Laboratory. 1982.

22. Stern S, Powers T, Changchien L-M, Noller HF. RNA-protein interactions in $30 \mathrm{~S}$ ribosomal subunits: folding and function of 16S rRNA. Science 1989 ; 244: 783-790.

23. Hogan JJ, Smith RD, Kop JA, McDonough SH. European patent application. Nucleic acid probes for detection and/ or quantification of non-viral organisms. 1987. Number 873110363.4

24. McFadden JJ, Butcher PD, Thompson J, Chiodini R, HermonTaylor $J$. The use of DNA probes identifying restrictionfragment-length polymorphisms to examine the Mycobacterium avium complex. Mol Microbiol 1987; 1 : 283-291.

25. Hurley SS, Splitter GA, Welch RA. Development of a diagnostic test for Johne's disease using a DNA hybridization probe. J Clin Microbiol 1989; 27 : 1582-1587.

26. Collins DM, Gabric DM, de Lisle GW. Identification of two groups of Mycobacterium paratuberculosis strains by restriction endonuclease analysis and DNA hybridization. J Clin Microbiol 1990; 28: 1591-1596. 